\title{
Store Layout and Customer Loyalty of Supermarkets in Port Harcourt, Nigeria
}

\author{
Onuoha A. Onuoha PhD, Nnenanya Doris \\ Department of Marketing, University of Port Harcourt, Port Harcourt, Nigeria
}

\begin{abstract}
This study examined the relationship between the multi-dimensionality of store layout and customer loyalty. Five hypotheses were formulated. To test the hypotheses, a survey of 400 respondents selected from ten supermarkets in Port Harcourt was carried out. Results showed positive relationship exists between each of the dimensions of store layout and customer loyalty. The study, therefore, concludes that store layout could be a means of gaining strong competitive advantage in a retail venture. Valuable means of achieving customer loyalty were also advanced in the study.
\end{abstract}

Keywords: Store layout, Customer loyalty, Supermarkets, Port Harcourt, Nigeria.

\section{INTRODUCTION}

Today's customers of retail outlets no longer based their purchase decisions only on product functions, features or attributes. They now seek for additional beneficial elements which have considerable influence on where they make their purchases; thus making retail competitive advantage to go beyond product, price, promotion and place (Baker et al 2003). One of such additional influential elements on customers' patronage of retail outlets, especially supermarkets, is store layout.

Store layout is an important element that encourages continuous customer patronage (loyalty) as well as useful determinant in the development of good store image (Baker et al, 2003) which leads to greater consumer elaboration and more positive consumer outcomes (Griffith, 2005). Taking a holistic and strategic approach to store layout can lead to greater payoffs in terms of increased sales, profitability and ultimately customer loyalty (Clark, 2003).

Several authors and researchers, including Zeynep and Nilgun (2011), Clark (2003), Baker et al (2003), Lewinson (1999), Griffith (2005) and Tiapana (2009) had affirmed store layout as a critical factor in today's retailing business. However, the works of these authors are foreign-based, with majority of them done in retail outlets other than supermarkets. As such virtually nothing has been done to scientifically test their veracities in Nigeria, in general and Port Harcourt in particular. This marks our point of departure as this study aims at establishing relationships among the dimensions of store layout used in this study and customer loyalty of supermarkets in Port Harcourt, Nigeria.

\section{LiteratURE REVIEW}

\subsection{Store Layout}

Store layout is the design of a store's interior for the ease of shopper movement within the store and maximum exposure of products displayed (Kalu et al, 2011). Thus, store layout includes doors, merchandise placement, shelf orientation, music, check-out counters, interior decoration, staff attitude, lighting and location of the loading facilities (Levy et al, 1995), as well as fixtures, product grouping/placement, traffic flow, department locations, allocation of floor space and allocations with department (Turkey \& Milliman, 2000). The essence of store layout is creating a positive store image in the minds of customers. In view of the above, Borges (2003) sees store layout as a huge and important duty of retail outlets managers, as it is one of the determinant factors of consumers' unplanned purchases (Bellizzi et al, 1992) and store loyalty (Miller \& Merildees, 2001). Store layout, therefore, shows the ultimate image of a store as well as shaping the perception of customers towards a store's environment (Tiapana, 2009).

\subsection{Dimensions of Store Layout}

A number of researchers have identified various dimensions of store layout. They include Levy at al (1995), Turkey and Milliman (2000), and Tiapana (2009). But without prejudice to that of other 
authors, the dimensions of store layout adopted in this study, as briefly explained below, are that of Tiapana (2009). The choice of these dimensions is based on the author's reported findings on the relationship between each of the dimensions and customer frequency of shopping at convenience stores in Kwa Mashu. However, the aim of this study is to establish relationship between each of these dimensions of store layout and customer loyalty of supermarkets.

\subsection{Product Assortment}

Product assortment is a critical element of store layout as it provides customers with the breadth and depth of product they want under one roof. A good product assortment entices customers to move within the store which could lead them to purchase more merchandize than may have planned originally (Levy \& Weitz, 2007). Stores that carry large assortments of products are often preferred by consumers for several reasons, including matching of specifications, convenience, ease of shopping and flexibility (Boatwright \& Nune, 2001).

\subsection{Merchandize Display}

Merchandize display, which is frequently used in store retailing (Zentes et al, 2007), refers to the way products are arranged in a store (Tiapana, 2009), and forms an integral component of the store image (McIntosh, 2007). Catchy merchandize display is capable of making shoppers to sacrifice the time and effort required to go a more distant store.

\subsection{Store Floor Space}

Store floor space is an in-store communications strategy aimed at making movement within a store easier and fun. Adequate store floor space requires enough space for easy movement in a store, easy entrance from outside the store and clear navigation and displays (Tiapana, 2009). Shoppers expected that space inside a store leads to experience of shopping pleasure (Wagner, 2007).

\subsection{Store Traffic Flow}

Shopping is one of exciting activities in life. Retail outlets are being designed to take care of the constantly changing taste and preference of shoppers. As part of leisure, most people, today, shop as families which sometimes create a traffic jam in a store. Thus, conducting a traffic flow analysis is a step in the right direction towards achieving customer loyalty. The essence of conducting store traffic flow analysis is to find out ways of making shopping and running the store easier, using layout and merchandising techniques in improving sales, stores appearance and making shopping more fun (Quiin and Steward, 2007). Thus, retail outlets manager should avoid congestions and heavy traffic flow in stores (Guy \& Duckett, 2003), as this has been found to be an important element in the success of retail store (Hui et al, 2007).

\subsection{Store Atmospherics (Music and Lighting)}

Store atmospherics have been affirmed, by shoppers, as important elements in store selection. This has made atmospherics which include music and lighting to receive considerable attention in the retail and services literature (Tiapana, 2009). For centuries, music and lighting had been acknowledged to have powerful effect on human response (Sweeney \& Wyber, 2002). Music influences consumers' retail purchase intentions (Tiapana, 2009). Thus, retail managers should know the music liked by their target market (Broekemieret et al, 2008). However, in general, a mix of classical or otherwise soothing music encourages shoppers to slow down, relax, and take a good look at the merchandise (Tiapana, 2009).

Lighting is a critical issue in today's fast growing retail trend (Zeynep \& Nilgun, 2011), as it involves more than simply illuminating space (Levy \& Weitz, 2007). Lighting highlights products, beautifies space and captures a mood or feeling that enhances the store's image (Tiapana, 2009), and also has the potential to affect sales dramatically (Levy \& Weitz, 2007).

\subsection{Customer Loyalty}

Customer loyalty is the willingness of a customer in maintaining his purchase relations with a firm and or its product (Kim \& Yoon, 2004). A loyal customer shows outstanding commitment to a firm, contributes to its profitability (Agu et al, 2015) and refers the firm and or its products to others (Mcllroy \& Barnett, 2000). Customer loyalty is categorized into components, including behavioural and attitudinal (Guillen et al, 2011); advocacy, retention and purchasing (Henning, 2010; Hayes, 
2012); repeaters, recommenders, reminders, rebuilders and reapers-developed and termed the "Five Rs" Model of customer loyalty by Agu and Okpara (2015). Continued existence and operation of a firm are ensured by customer loyalty (Chen \& Hu, 2010), which can be influenced by management action (Gerpott et al, 2001).

In view of the foregoing, managers of retail outlets have recognized store layout as a significant factor in influencing consumer buying decisions (Schiffman \& Kanuk, 2002), and as a key element in ensuring customer loyalty (Pan et al, 2008).

Based on the above literature, the theoretical framework as shown in Figure 1 was developed.

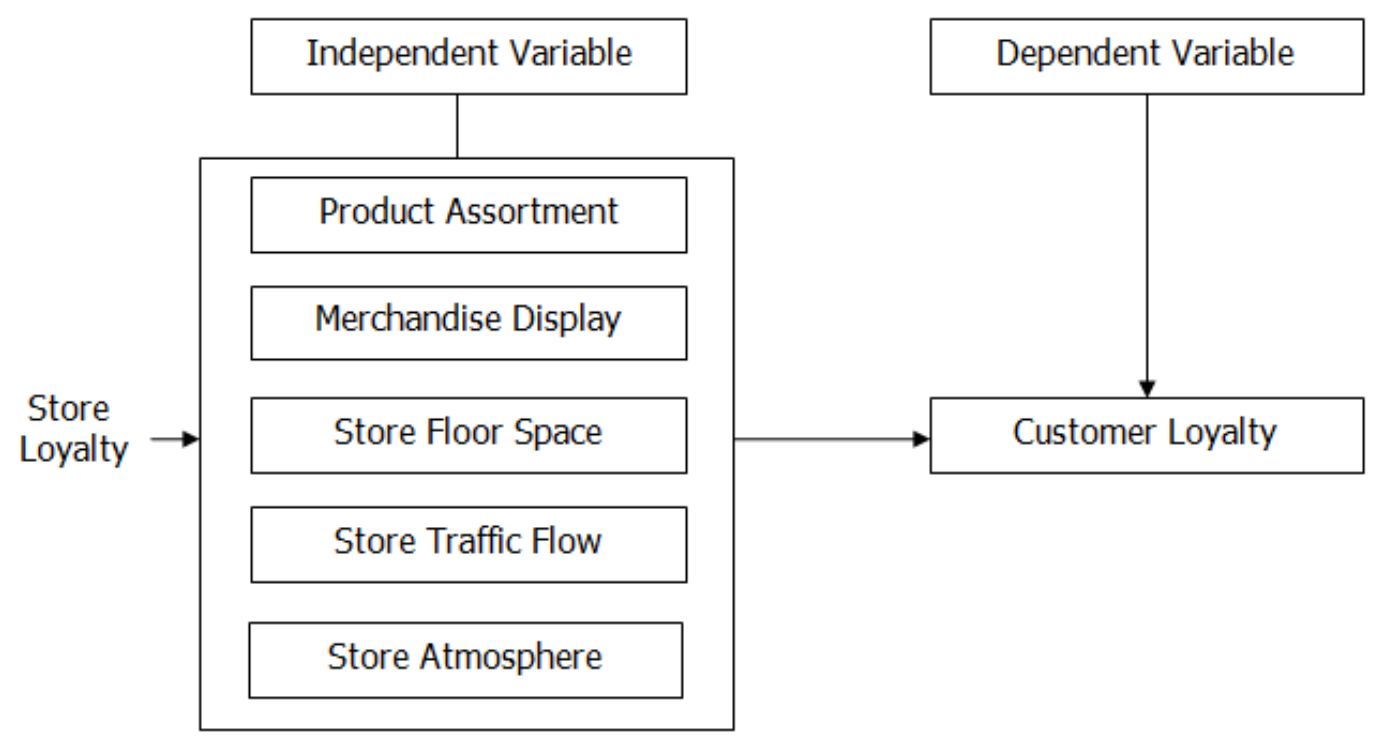

Figure1. Theoretical Framework of Store Layout and Customer Loyalty Source: Desk Research, 2016

Based on the theoretical framework, certain hypotheses as stated below were formulated for the study.

$\mathrm{Ho}_{1}$ : Product assortment has significant relationship with customer loyalty

$\mathrm{Ho}_{2}$ : Merchandize display has significant relationship with customer loyalty

$\mathrm{Ho}_{3}$ : Store floor space has significant relationship with customer loyalty

$\mathrm{Ho}_{4}$ : Store traffic flow has significant relationship with customer loyalty.

$\mathrm{Ho}_{5}$ : Store atmospherics have significant relationship with customer loyalty.

\section{METHODS AND INSTRUMENTS}

This study was carried out in Port Harcourt, Nigeria. The city has an estimated population of $1,947,000$ as at March, 2015 (www.takemetonaija.com). Due to difficulties in covering the population, a sample was drawn from the population. For a population of 1,000,000 and above, 384 is adequate as a sample size (Sekaran, 2003).

However, for the purpose of this study, the sample size was increased to 400 , to ensure even distribution of the research instrument in the selected supermarkets.

Data were collected from 400 customers of 10 supermarkets drawn from 5 areas of Port Harcourt Diobu, Borokiri, New GRA, Old GRA and Port Harcourt City - using structured questionnaire, on the basis of 2 supermarkets per area. However, all elements that constituted the sample size were people who were shopping in or leaving the store after purchase as at the time the researchers visited the supermarkets selected for study. This is referred to as convenience sampling as it is based accessibility (Ezejelue et al, 2008).

The questionnaire used for the study had two sections - A and B. Section A contained 5 sub-sections, each with statements relating to a particular store layout dimension as follows; Product Assortment (5 items), Merchandise Display (8 items), Store Floor Space (5 items), Store Traffic Flow (6 items) and Store Atmospherics ( 7 items). Section B measured Customer Loyalty with 5 items. Respondents were to rate each statement or items using a 5-point Likert Scale of Strongly Agree (5), Agree (4), Neutral 
(3), Disagree (2) and Strongly Disagree (1). The questionnaire was pre-tested on 20 respondents from 2 of the supermarkets studied.

The reported Cronbach alphas are as follows: Product Assortment 0.75, Merchandize Display 0.78, Store Floor Space 0.71, Store Traffic Flow 0.77, Store Atmospherics 0.76 and Customer Loyalty 0.71. The coefficient values were all above 0.7, thus meeting Nunnally's (1978) recommendation of greater than 0.70 . Pearson's correlation was used to establish the relationship between store layout and customer loyalty.

\section{RESUlts}

The five hypotheses formulated for the study were tested using Pearson's Product Moment Correlation Coefficient. Results from the study, as contained in Table 1, shows a significant positive relationship between product assortment and customer loyalty $(\mathrm{r}=0.926, \mathrm{p}<0.01)$. This is an indication that adequate product assortment leads to customer loyalty. Again, the Table shows that merchandise display has significant relationship with customer loyalty $(\mathrm{r}=0.944, \mathrm{p}<0.01)$, signifying that improved merchandize display leads to customer loyalty. It is also shown in the Table that store floor space is significantly related to customer loyalty $(r=0.979, p<0.01)$, following the same trend where improvement in store floor space leads to customer loyalty. Also from the Table, store traffic flow was found to have significant relationship with customer loyalty $(r=0.959, p$ $<0.01$ ), indicating that adequate management of traffic flow within a store leads to customer loyalty. Finally, the Table also shows that store atmospherics are significantly related to customer loyalty $(\mathrm{r}=$ $0.897, \mathrm{p}<0.01$ ), which indicates that improved store atmospherics lead to customer loyalty.

Table1. Correlations

\begin{tabular}{|l|l|l|l|l|l|l|}
\hline \multicolumn{1}{|c|}{ Variable } & $\begin{array}{c}\text { Customer } \\
\text { Loyalty }\end{array}$ & $\begin{array}{c}\text { Product } \\
\text { Assortment }\end{array}$ & $\begin{array}{c}\text { Merchandise } \\
\text { Display }\end{array}$ & $\begin{array}{c}\text { Store Floor } \\
\text { Space }\end{array}$ & $\begin{array}{c}\text { Store } \\
\text { Traffic Flow }\end{array}$ & $\begin{array}{c}\text { Store } \\
\text { Atmospherics }\end{array}$ \\
\hline $\begin{array}{l}\text { Customer } \\
\text { Loyalty }\end{array}$ & & & & & & \\
\hline $\begin{array}{l}\text { Product } \\
\text { Assortment }\end{array}$ & & $.926^{* *}$ & & & & \\
\hline $\begin{array}{l}\text { Merchandise } \\
\text { Display }\end{array}$ & & & $.944^{* *}$ & & & \\
\hline $\begin{array}{l}\text { Store Floor } \\
\text { Space }\end{array}$ & & & & $.979^{* *}$ & & \\
\hline $\begin{array}{l}\text { Store Traffic } \\
\text { Flow }\end{array}$ & & & & & $.959^{* * *}$ & \\
\hline $\begin{array}{l}\text { Store } \\
\text { Atmospherics }\end{array}$ & & & & & & $.897^{* *}$ \\
\hline
\end{tabular}

**Correlation is significant at the .01 level (2-tailed), $N=400$

\section{Discussion OF RESUlts}

The results supported all the five hypotheses formulated for the study. The test of hypothesis one shows that product assortment was positive related to customer loyalty. This finding is consistent with previous studies that found that a good product assortment boosts sales by enticing customers to purchase more than they originally planned and ultimately leads to customer loyalty (Clark, 2003; Levy \& Weitz, 2007).

The test of hypothesis two shows a positive and significant relationship between merchandize display and customer loyalty. This finding is supported by previous studies which affirmed that appropriate merchandize display is a premium to a retail outlet (Mitchell and Ingram, 2002; McIntosh, 2007).

The result of the test of hypothesis three shows that store floor space has significant relationship with customer loyalty. Store floor space has been found by other studies, for example Michon et al (2008), Wagner (20070 and Griffith (2005), to be a critical factor driving consumer response in terms of repeat purchases.

Evidence from the test of hypothesis four shows a significant relationship between store traffic flow and customer loyalty. Other studies that affirmed this finding include Quinn and Stewart (2007) and Hui et al (2007) as they found out that proper management of in-store traffic flow plays an important role in the success of a retail outlet. 
Finally, the test of hypothesis four shows a significant relationship between store atmospherics and customer loyalty. Store atmospherics, including music and lighting, have been used in creating certain effects on buyers (Tiapana, 2009). Other studies that also support our finding include Levy and Weitz (2007), Broekemier et al (2008) and Sweeney and Wyber (2002).

\section{Conclusion}

This study sought to establish a relationship between store layout and customer loyalty of supermarkets in Port Harcourt. Dimensions of store layout, as used in this study, and customer loyalty were discussed, and hypotheses formulated therefrom. The results of the test of the hypotheses show that store layout has strong significant relationship with customer loyalty. Thus, providing good store layout could be a means of gaining strong competitive advantage in a retail venture.

\section{RECOMMENDATIONS}

1. Product assortment is a critical factor in achieving customer loyalty as findings indicated. Therefore, supermarkets in Port Harcourt should ensure that needed products are stock, in breadth and depth, to avoid out-of-stock which typically leads to lost of goodwill, sales, revenue and customer loyalty.

2. Supermarkets should ensure that available products are attractively displayed on shelves. Thus, eye-catching and appealing display is recommended. Moreover, complementary products should be displayed close to each other, as this would minimize customers' time expense and makes shopping efficient.

3. Supermarket owners should ensure that enough space is left between shelves for easy movement in the store, especially these days that most families take shopping trips as part of their leisure. Inadequate space between shelves can make movement uncomfortable, thereby making the shopping experience displeasurable.

4. To ensure adequate store traffic flow, supermarkets owners should adopt the strategy of establishing aisles that are narrow enough to make customers to slow down, which will give them enough time to notice products displayed, but not so narrow that they create a traffic jam.

5. Store owners should ensure adequate use of music and lighting in their stores, as they have been acknowledged for centuries to have powerful effects on human responses. Besides lights that should make the store looks bright and inviting as well as enable customers to see products clearly, store owners should ensure that background soothing music that would make shoppers to slow down, relax and take a good look at products are played. However, the sound should not be allowed to degenerate to noise, as music is successive sounds which are pleasant to the ear.

\section{REFERENCES}

Agu, G. A. and Okpara, G. S. (2015). Comparative complaint management strategies in organized road transport firms in Imo State. Journal of Marketing Research, 3 (1):1-15.

Agu, G. A., Madumere, H. I., Samuel, E., Ohuonu, O. N., Kalu, I. N. and Onyeagwara, C. O. (2015). Rating of factors influencing subscribers' loyalty to GSM network providers in South East, Nigeria. Journal of Business and Value Creation, 4 (2): 96 - 113.

Baker, J., Grewel, D., Parasuraman, A. and Voss, G. B. (2003). The influence of multiple store environment cues on perceived merchandize value and patronage intentions. Journal of Retailing, 79: 259-268.

Bellizzi, J. A., Crowley, A. E. and Hasty, R. W. (1992). The effect of color in store design. Journal of Retail, 59:21-45.

Boatwright, P. and Nunes, J. C. (2001). Reducing assortment: An attribute-based approach. Journal of Marketing, 65 (3): 50.

Borges, A. (2003). Towards a new supermarket layout: From industrial categories to one stop shopping organization through a data mining approach. Preceding of the 2003 SMA Retail Symposium, New Orleans, USA.

Broekemier, G., Marquardt, R. and Gentry, J. W. (2008). An exploration of happy/sad and liked/disliked music effects on shopping intentions in women's clothing store service setting. Journal of Services Marketing, 22 (1): 59-67.

Chen, P. T. and Hu, H. H. (2010). The effect of relational benefits on perceived value in relation to customer loyalty: An empirical study in the Australian Coffee outlets industry. International Journal of Hospitality Management, 29:405-412. 
Ezejelue, A. C., Ogwo, E. O. and Nkamnebe, A. D. (2008). Basic Principles in Managing Research Projects, $2^{\text {nd }}$ ed., Aba: Afritower Limited.

Gerpott, T. J., Rams, W. and Schindler, A. (2001). Customer retention, loyalty and satisfaction in the German mobile cellular telecommunication market. Telecommunication Policy, 25: 249-269.

Griffitth, D. A. (2005). An examination of the influences of store layout in online retailing. Journal of Business Research, 58 (10): 1391 - 1396.

Guy, C. and Duckett, M. (2003). Small retailers in an inner city community: A case study of Adamsdown, Cardiff. International Journal of Retail and Distribution Management, 31(8): 401407.

Hayes, B. E. (2012). Visualizing the three components of customer loyalty (online). Available: www.biz-broadway.com (October 9, 2016).

Henning, J. (2010). Loyalty triad: Three separate components of customer loyalty (online). Available: www.vovici.com (October 9, 2016).

Hui, E. C. M., Yui, C. Y. and Yau, Y. (2007). Retail properties in Hong Kong: A rental analysis. Journal of Property Investment and Finance, 25 (2): 136 - 146.

Kalu, S. E., Ekeke, J. N., Ogbuji, C. N. and Ikechi, P. O. (2011). Retail and Wholesale Management in Nigeria. Owerri: Stramark Communication Consult.

Kim, H. S. and Yoou, C. H. (2004). Determinants of subscriber chum and customer loyalty in the Korean mobile telephony market. Telecommunications Policy, 28:751 - 765

Levy, M., Weitz, B. A. and Beattie, S. (1995). Retailing management (online). Available www. shcjdx.mba.net/catalogue/syllabus/2006 WINTER MARK 468 LEC B1. pdf (October 9, 2016).

Levy, M. and Weitz, B. A. (2007). Retail Management, $7^{\text {th }}$ ed. New York: McGraw-Hill.

Lewinson, D. M. (1999). Retailing, $6^{\text {th }}$ ed. New Jersey: Prentice-Hall.

McIntosh, M. (2007). The importance of retail merchandizing (online). Available: www.sideroad. com/Retail_Services/retail_merchandising.html (May 23, 2015).

McIlroy, A. and Barnett, S. (2000). Building customer relationship: Do discount cards work? Managing Service Quality, 10 (6): 347 - 355.

Michon, R., Yu, H., Smith, D. and Chebat, J. C. (2008). The influence of mall environment on female fashion shoppers' value and behavior. Journal of Fashion Marketing and Management, 12 (4): 456-466.

Miller, D. and Mervilees, B. (2001). Superstore interactivity: A new self service paradigm of retail service. International Journal of Retail and Distribution Management, 29 (8): 379 - 389.

Mitchell, P. and Ingram, H. (2002). Space revenue and valuation models in retailing and hotels. International Journal of Contemporary Hospitality Management, 14 (1): 28-33.

Nunnally, J. C. (1978). Psychometric Theory, $2^{\text {nd }}$ ed. New York: McGraw Hill.

Pan, F. C., Su, S. J. and Chiang, C. C. (2008). Dual attractiveness of winery: Atmospheric cues on purchasing. International Journal of Wine Business Research, 20 (2): 95-110.

Quinn, C. and Steward, R. (2007). Improving performance: Conducting a traffic flow analysis (online). Available: www.cooperativegrocer.coop/articles/index.php?id=79 (October 9, 2016).

Schiffman, U. (2003). Research Methods for Business, $4^{\text {th }}$ ed. New York: John Wiley \& Sons, Inc.

Sweeney, J. C. and Wyber, F. (2002). The role of cognitions and emotions in the music-approachavoidance behavior relationship. Journal of Services Marketing, 16 (1): 51-69.

Tiapana, T. P. (2009). Store layout and its impact on consumer purchase behavior at convenience stores in Kwa Mashu. Unpublished Dissertation, Durban University of Technology.

Turley, L. W. and Milliman, R. E. (2000). Atmospheric effects on shopping behavior: A review of the experimental evidence. Journal of Business Research, 49 (2): 193 - 211.

Wagner, T. (2007). Shopping motivation revised: A means-end chain analytical perspective. International Journal of Retail and Distribution Management, 35 (7): 569-582.

Zentes, J., Morschett, D. and Schramm-Klein, H. (2007). Strategic Retail Management: Text and International Cases. Wiesbaden: Gabler.

Zeynap, E. and Nilgum, G. (2011). Congruence between Atmospheric cues and Store Image in Fashion Retailing. Turkey: Izmir University of Economics. 